\title{
Internet of Things (IoT) based counsellor skills 21st century
}

\section{Citra Tectona Suryawati, Agus Tri Susilo, Ribut Purwaningrum, Asrowi}

\author{
Universitas Sebelas Maret \\ citratectonas@staff.uns.ac.id
}

Submitted : 13-07-2021, Revised : 25-11-2021, Accepted : 29-11-2021

\begin{abstract}
The rapid development of the era requires guidance and counseling teachers to be more creative in providing services. The purpose of this study is to determine the level of 21st century skills based on the Internet of Things (IoT) based on categorization. The sample of this study was 53 people consisting of school counselors in Sukoharjo and students of professional education and counselling teachers at one university. The method used is a one-shot case study. The results showed that the average 21st century counsellor's skills of $54.3 \%$ were in the 'medium' category. This can be interpreted that the skills of 21st century counsellor when participating in IoT-based skills development workshops have good criteria. However, it is possible that there is a need to improve skills again so that the quality of guidance and counselling services is getting better and more effective.
\end{abstract}

Keywords: 21st century skills; Counsellor; Internet of Things (IoT)

\section{Introduction}

Counselors are now faced with new challenges. The rapid development of the times requires counselors to be more creative in providing services. The sign that times are developing rapidly is that we have arrived at the 21st century generation. This 21st century demands professional development in all lines of work that are in accordance with the times for a counselor to provide services to counselees. The counselor profession has objective measures/parameters in recognizing and describing the level of professionalism, namely in terms of academic qualifications, fulfillment of work standards and fulfillment of professional requirements. Counselors are one of the most prestigious professions in the development of the 21st century, because the counselor profession is closely related to developmental problems in aspects of human development, how they deal with and act in the social environment they are in. Counselors must also keep up with the times so that the services provided can be in accordance with the trend of student needs (El Mrabet \& Moussa, 2019)

The problems faced by humans become increasingly complex when entering the digital era with technological advances or commonly referred to as the era of globalization which makes the development of human mobility fast-paced. The era of globalization causes fundamental changes that are different from the previous order of human life (Wijaya et al., 2016). These changes occurred in the era of revolution 4.0 which was also experienced by the younger generation. The problems experienced by humans also apply to students who are the younger generation. Because of this, these students or the younger generation need treatment that demands qualified skills and competencies from guidance and counseling teachers. In the implementation of guidance and counseling so that students can better understand, understand, and internalize the material for guidance and counseling services, teachers must be able to provide appropriate services and understand these services (Alhadi et al., 2016).

The young generation who is the millennial generation in this era is facilitated with many conveniences in various things (Rakhmawati, 2017). Of course, these facilities have both positive and negative impacts on the subjects. The era of revolution 4.0 also has an impact on 
the level of competition that is getting tougher and of course requires effort to be the one. This level of competition occurs in various lines of life, ranging from the realm of education to the realm of work. This has resulted in the need for various efforts to shape and prepare today's millennial generation so that they can become a superior generation and become winners in various tight competitions in the world. Therefore, the presence of a professional counselor is a necessity and an important point in the world of education.

Lau et al (2019) dan Yusri (2013) placing the school counselor profession into the top 10 professions that are needed in today's globalization era. The need for the counselor profession itself raises its own opportunities as well as challenges in the current era of globalization.

This global challenge for counselors needs to be answered and addressed by practitioners in the field of counseling guidance. These global challenges are ten challenges in the 21st century, namely: (1) speed, (2) convenience, (3) age wave, (4) choice, (5) life style, (6) discounting, (7) value added, ( 8) customer service, (9) techno age, and (10) quality control (Nugroho, 2021). Counselors should be able to adapt by developing skills to meet these challenges.

The challenges that arise in the 21st century can be answered by developing four skills. Zain (2017) explains the four skills needed in the 21st century, namely critical thinking, communication, collaboration, creativity. These four skills should be applied to the process of learning and innovating in developing life skills and career development. In addition, the skills to process information, media, and technology must be given to students so that they understand technology. These four skills need to be followed up by the counselor in order to develop the professional competence of 21st century teachers. The four challenges that have been expressed above are expected to be fulfilled by the counselor so that the competence of the counselor continues to develop following the changing times.

The results of the preliminary study conducted showed that from 68 counselors there were still 18 counselors who had 21st century skills in the low category. Whereas professional counselors are required to continue to develop their competencies according to the needs, demands of society, and the times. Currently, the profession of guidance and counseling teachers is not limited only to the field of education in schools, but the wider community also requires the role and presence of qualified counselors. Counselors should be able to further increase their capacity to become someone who is qualified and sensitive to the rapid development of the times (Imawanty \& Fransiska, 2019).

The skills that teachers should have in the 21st century according to Griffin et al (2012) are divided into four important skills, namely the way of thinking, the way of working, the tool of working, and living in the world. The skills of teachers in the first 21st century are way of thinking, such as the ability to generate creativity, the ability to solve problems, innovate, the ability to make decisions, think critically, the willingness to continue learning, and the ability to manage cognitive aspects. The second skill is the way of working, which focuses on the ability to communicate and the ability to work together. The third skill is the tool of working, which includes the ability to perform literacy and utilize information and communication technology. The fourth skill is living in the world, namely being a responsible person, loving the homeland, knowing about future careers, and having cultural awareness.

In the 21st century, humans are inseparable from the digital era (Notanubun, 2019). Learning styles and teaching and learning tools have shifted from being conventional in the form of printed books to technology-based, for example digital/online books or even online journal references. So it's not surprising that the 21st century demands competent skills and competencies in terms of how to act and think, work to settle bills, manage technology, and view and perceive as citizens of the world (Care et al., 2017; Notanubun, 2019). The provision of services provided by guidance and counseling teachers should be in accordance with the 
times, therefore guidance and counseling teachers should have skills that support the times in providing services to students. Utilization of this technology can be applied in everyday life to facilitate the performance of counselors. This is commonly referred to as the Internet of Things (IoT).

Internet of Things (IoT) is a computing concept of everyday objects that are connected to the internet and are able to identify themselves to other devices. Internet of Things is a structure in which objects, people are provided with exclusive identities and the ability to move data over a network without requiring two-way human-to-human i.e. source-to-destination or human-to-computer interaction (Burange \& Misalkar, 2015; Kaushik \& Bagga, 2020). With the development of the Internet of Things (IoT), the internet can also be used for other purposes that support learning (Prihatmoko, 2016). The existence of the Internet of Things (IoT) is starting to dominate human work, it is even possible to reduce human interaction. Including the performance of counselors who also need the internet to support work. for example, processing assessment data, providing online services, to developing professionalism by conducting research. It is hoped that the Internet of Things can help the 21st century skills of counselors.

\section{Method}

The design of this research is a one-shot case study. The sampling technique used purposive sampling. The subjects in this study amounted to 53 people consisting of counselors in Sukoharjo and counselors for teacher education students at one of the universities in Solo. The data was obtained from an instrument that was developed based on indicators of 21st century skills, namely critical thinking, communication, cooperation and creativity. This instrument is in the form of a scale that is used to measure 21st century skills during the process of implementing the internet of things (IoT) based 21st century BK teacher skill development workshop. Data analysis was carried out by calculating the percentage of 21st century skills. The data obtained were interpreted descriptively for each skill indicator.

\section{Results and Discussion \\ Results}

The workshop on developing 21st century counselor skills based on the internet of things (IoT) was carried out for 4 meetings by integrating 21st century skills, namely Communication, Collaboration, Creativity and Critical thinking. The results of the analysis of the 21st century counselor skills on each indicator are shown in the score table below:

Table 1 Score of 21st Century Counselor Skills

\begin{tabular}{lllll}
\hline & $\begin{array}{c}\text { 21st Century } \\
\text { Skills } \\
\text { Indicators }\end{array}$ & \multicolumn{2}{c}{ Number of Respondents } \\
\cline { 2 - 5 } No & & Low & Medium & High \\
\hline & $\begin{array}{l}\text { Critical } \\
1\end{array}$ & 14 & 29 & 10 \\
\hline 2 & Cominking & & & \\
\hline 3 & Collaboration & 9 & 30 & 14 \\
\hline 4 & Creativity & 13 & 30 & 14 \\
\hline
\end{tabular}


The table shows the number of respondents in each aspect of 21st century skills. In the critical thinking aspect there are 14 people in the low category, 29 people in the high category and 10 people in the high category. In the aspect of communication, 4 people are in the low category, 27 people are in the medium category and 22 are in the high category. In the third aspect, namely cooperation, 9 people are in the low category, 30 people are in the medium category and 14 people are in the high category. As for the creativity aspect, 13 people are in the low category, 30 people are in the medium category and 14 people are in the high category. Based on the results of these four aspects, it can be concluded that the average counselor in Sukoharjo and students of the teaching profession who have become counselors are in the medium category. This can be interpreted that the 21st century counselor skills at the time of attending the workshop have "good" criteria. In the medium category, it is ranked the highest, but it is possible to give efforts to develop 21st century skills again so that counselors can be more professional in providing services. This shows that the more IoT-based 21st century skills are developed, the better the quality of service in schools will be.

\section{Discussion}

The development of 21st century skills is indispensable in various professions in today's digital era. It also requires counselors to develop their competencies, including the competence to utilize technology in providing services to students. The use of this technology is in accordance with the characteristics of 21st century students. The characteristics of 21st century students are marked by the rapidly increasing use of the internet. Therefore, counselors need to be able to take advantage of the internet and its technology. Notanubun (2019) stated that in the current era, the 21st century, the need for teacher competence in operating technology to design innovative and creative learning is very necessary. With this creative learning, counseling services will be more effectively accepted by students. Media in guidance and counseling services plays an important role in the implementation of guidance and counseling so that students can better understand, understand, and internalize the material for guidance and counseling services to students (Alhadi et al., 2016).

The results showed that the average teacher was in the "medium" category after attending a 21st century skills development workshop based on the internet of things. This shows that internet of things-based workshops have a positive impact on the development of 21st century skills. The skills of internet of things-based counselors are only basic, such as using zoom, utilizing technology such as infocus, speakers and media such as power points. These uses of technology indicate that the 21st century counselor's skills are quite good. This skill is in the medium category so it is quite good in general due to the demands of the times and also the supporting infrastructure. Although it is still minimal in use, it is already a good start. Indeed, it is a challenge for counselors who have served several generations to penetrate the world of the internet and technology. Rakhmawati (2017) revealed that although the use of technology in providing services is a challenge for some school counselors/counselors, it is undeniable that technological advances provide opportunities for school counselors to meet student needs more efficiently and effectively. Technology-based school counseling programs, form a more effective school environment and provide students with better development opportunities.

Counselors should further develop their abilities in 21st Century skills in providing counseling guidance services that can be accessed anywhere, anytime and always online. Counselors must be able to further develop their abilities, namely 21st century skills in developing and utilizing the resources available on the internet to the maximum, considering that students are Generation $\mathrm{Z}$ who have high digital literacy. Therefore, it is very necessary for counselors to innovate. In this era of the industrial revolution 4.0, guidance and counseling teachers need a change in perspective in providing services in the millennial era in a more 
efficient, effective, and flexible way (Indrawan et al., 2019). One of them is by providing services and providing media that are asynchronous or synchronous. Services that are carried out synchronously and asynchronously can make it easier for counselors to reach all student needs (Cooper et al., 2019; Supriyanto et al., 2020)

Generation $\mathrm{Z}$ or the generation in the 21st century requires the role of a school counselor to provide up to date counseling services (Koltz, 2021; Vatmawati \& Nurawinata, 2018). Innovation and use of information technology-based media will be very interesting and make it easier for students and counselors to acknowledge the service process. In addition, counselors can also use internet media to develop their competencies related to professionalism. This is reinforced by the opinion Barker et al (2018) which states that the knowledge and innovative works that have been produced by counselors can be shared by other counselors via the internet, so that it will spur counselors as educators who are professional, innovative and develop following new dynamics.

\section{Conclusions and Suggestions}

\section{Conclusions}

The growing digital era requires counselors to provide services using technology and the internet. This will be accompanied by the demands of the counselor's skills in operating technology. The level of ability of counselors varies in using the internet and this technology. As well as the results of this study conducted on counselors in Sukoharjo Regency.

The limitations in this study are that the subject used is only a representative of 1 (one) counselor from each junior high and high school equivalent in Sukoharjo Regency and counselors who are teacher education students at one university.

\section{Suggestions}

Suggestions for further researchers can conduct research using other methods to be richer and exploratory. In addition, it is also recommended for further researchers to use a larger population and subject so that the results are also more comprehensive.

\section{References}

Alhadi, S., Supriyanto, A., \& Dina, D. A. M. (2016). Media in guidance and counseling services: a tool and innovation for school counselor. SCHOULID: Indonesian Journal of School Counseling, 1(1), 6-11.

Barker, E. T., Howard, A. L., Villemaire-Krajden, R., \& Galambos, N. L. (2018). The rise and fall of depressive symptoms and academic stress in two samples of university students. Journal of Youth and Adolescence, 47(6), 1252-1266.

Burange, A. W., \& Misalkar, H. D. (2015). Review of Internet of Things in development of smart cities with data management \& privacy. 2015 International Conference on Advances in Computer Engineering and Applications, 189-195.

Care, E., Kim, H., Anderson, K., \& Gustafsson-Wright, E. (2017). Skills for a Changing World: National Perspectives and the Global Movement. Center for Universal Education at The Brookings Institution.

Cooper, S. E., Campbell, L. F., \& Smucker Barnwell, S. (2019). Telepsychology: a primer for counseling psychologists. The Counseling Psychologist, 47(8), 1074-1114. 
El Mrabet, H., \& Moussa, A. A. (2019). Smart school guidance and vocational guidance system through the internet of things. Proceedings of the 2nd International Conference on Networking, Information Systems \& Security, 1-5.

Griffin, P., Care, E., \& McGaw, B. (2012). The changing role of education and schools. In Assessment and teaching of 21st century skills (pp. 1-15). Springer.

Imawanty, I., \& Fransiska, A. B. (2019). Guru Bimbingan dan Konseling Berkualitas di Era Revolusi 4.0: Pembelajar, Kompeten, dan up to Date. Prosiding Seminar Nasional Pendidikan FKIP, 2(1), 147-153.

Indrawan, P. A., Lay, A. E., \& Cendana, O. N. (2019). Guidance and Counseling Teachers' Competency Perspective in the Era of Industrial Revolution 4.0. The International Journal of Innovation, Creativity and Change, 5(3), 147-161.

Kaushik, N., \& Bagga, T. (2020). Internet of Things (IOT): Implications in Society. Proceedings of the International Conference on Innovative Computing \& Communications (ICICC).

Koltz, J. L. (2021). Supporting Perceived Academic Stress: An Online Delivered Counseling Intervention for Middle School Students. University of Nevada, Reno.

Lau, J., Garza, T., \& Garcia, H. (2019). International students in community colleges: Oncampus services used and its affect on sense of belonging. Community College Journal of Research and Practice, 43(2), 109-121.

Notanubun, Z. (2019). Pengembangan kompetensi profesionalisme guru di era digital (Abad 21). Jurnal Bimbingan Dan Konseling Terapan, 3(2), 54-64.

Nugroho, A. R. (2021). Transformation of Guidance and Counselling Teacher Facing the Industrial Revolution 4.0 Era. 2nd Annual Conference on Blended Learning, Educational Technology and Innovation (ACBLETI 2020), 189-191.

Prihatmoko, D. (2016). Penerapan internet of things (IoT) dalam pembelajaran di UNISNU Jepara. Simetris: Jurnal Teknik Mesin, Elektro Dan Ilmu Komputer, 7(2), 567-574.

Rakhmawati, D. (2017). Konselor sekolah abad 21: tantangan dan peluang. Jurnal Konseling GUSJIGANG, 3(1).

Supriyanto, A., Hartini, S., Irdasari, W. N., Miftahul, A., Oktapiana, S., \& Mumpuni, S. D. (2020). Teacher professional quality: Counselling services with technology in Pandemic Covid-19. Counsellia: Jurnal Bimbingan Dan Konseling, 10(2), 176-189.

Vatmawati, S., \& Nurawinata, H. (2018). PERAN GURU BK ABAD 21 DALAM MENINGKATKAN KEMAMPUAN PERENCANAAN KARIER SISWA SMP. SEMINAR NASIONAL BIMBINGAN KONSELING 2017.

Wijaya, E. Y., Sudjimat, D. A., Nyoto, A., \& Malang, U. N. (2016). Transformasi pendidikan abad 21 sebagai tuntutan pengembangan sumber daya manusia di era global. Prosiding Seminar Nasional Pendidikan Matematika, 1(26), 263-278.

Yusri, F. (2013). Perkembangan Profesional Konselor Untuk Memenuhi Kebutuhan Masyarakat Industri. Jurnal Konseling Dan Pendidikan, 1(1), 36-42. 
Zain, I. M. (2017). The Collaborative Instructional Design System (CIDS): Visualizing the 21st Century Learning. Universal Journal of Educational Research, 5(12), 2259-2266. 
